\title{
A Review of Cord Blood Concentrations of Iron Status Parameters to Define Reference Ranges for Preterm Infants
}

\author{
Laila Lorenz $^{\mathrm{a}}$ Andreas Peter ${ }^{\mathrm{c}}$ Christian F. Poets $^{\mathrm{a}} \quad$ Axel R. Franz $^{\mathrm{a}, \mathrm{b}}$ \\ ${ }^{a}$ Department of Neonatology and ${ }^{b}$ Center for Pediatric Clinical Studies, University Children's Hospital of \\ Tübingen, and 'Division of Endocrinology, Metabolism, Pathobiochemistry and Clinical Chemistry, Department of \\ Internal Medicine, University of Tübingen, Tübingen, Germany
}

\section{Key Words}

Iron deficiency · Premature infant . Cord blood .

Hemoglobin · Mean corpuscular volume $\cdot$ Soluble transferrin receptor - Transferrin saturation - Reticulocyte hemoglobin content $\cdot$ Zinc protoporphyrin/heme ratio . Hepcidin

\begin{abstract}
Background: Iron plays an essential role in various tissue functions, and hence the reliable assessment of iron nutrition status of preterm infants appears to be mandatory. $\mathbf{O b}$ jectives: To summarize available data on cord blood concentrations of iron status parameters as surrogate reference ranges for preterm infants until term-equivalent age. Methods: Review of the literature searching PubMed for cord blood values of hemoglobin, mean corpuscular volume, ferritin, soluble transferrin receptor, ferritin index, transferrin saturation, reticulocyte hemoglobin content, zinc protoporphyrin/heme ratio, and hepcidin and comparison with reference ranges established for adults. Results: Gestational agespecific cord blood concentration ranges at term were computed as weighted mean for hemoglobin $[15.9 \mathrm{~g} / \mathrm{dl}$ (13.3-18.4)], mean corpuscular volume [108.1 fl (97.8-118.5)] and transferrin saturation [61.2\% (31.5-90.9)] and listed for ferritin, soluble transferrin receptor, ferritin index, zinc pro-
\end{abstract}

\section{KARGER}

E-Mail karger@karger.com

www.karger.com/neo toporphyrin/heme ratio, reticulocyte hemoglobin content and hepcidin. These surrogate reference ranges were markedly different from adult values. Conclusion: Reference ranges of iron status parameters established for adults are probably not suitable to define iron status in preterm infants. If iron supplementation in preterm infants should be individually adjusted based on iron status parameters, it may be necessary to aim for cord blood concentration ranges to enable optimal growth and development. @ $2013 \mathrm{~S}$. Karger AG, Basel

\section{Introduction}

Most fetal iron is transferred from mother to fetus during the third trimester of gestation [reviewed in 1]. This transfer is interrupted by preterm birth, resulting in iron stores at birth being proportional to birthweight $[2,3]$. Despite low iron stores at birth, growth velocity of very premature infants is maximal at 28-38 weeks' postmenstrual age reflecting a particularly high iron need during this period [4]. The risk of iron deficiency (ID) in preterm infants is further increased by frequent uncompensated iatrogenic phlebotomy losses [5].

Untreated ID in preterm infants during the fetal and postnatal period may contribute to long-term neurode- 
velopmental impairments that cannot be corrected by later iron supplementation [reviewed in 6, 7]. For instance, preterm infants with anemia and low ferritin had an increased number of abnormal reflexes evaluated according to the Assessment of Premature Infants Behavior at 37 weeks' postmenstrual age compared to nonanemic preterm infants [8].

Early enteral iron supplementation in very preterm infants reduces the incidence of ID and the need of red blood cell (RBC) transfusion $[9,10]$ and moreover may be associated with fewer long-term neurological abnormalities compared to those supplemented late [11]. Because enteral iron absorption is highly variable (range: 10-50\%) $[12,13]$, an oral iron dose of $4-6 \mathrm{mg} / \mathrm{kg} /$ day may not be sufficient for all preterm infants depending of individual enteral iron absorption and iatrogenic iron loss [10].

In contrast, iron excess may increase the production of oxygen radicals to which preterm infants are especially vulnerable, because of low antioxidant capacity [14]. Fortunately, enteral iron has not been shown to increase markers of oxidative injury [15-17]. Nevertheless, side effects of oral iron supplementation such as lower rate of weight gain [18] and impaired growth in length [19] have been described in older, iron-replete children. However, this has not been observed in very [11] and marginally low birthweight infants [20].

According to both European and American recommendations, all preterm infants should be supplemented with $2-3 \mathrm{mg} / \mathrm{kg} /$ day of elemental iron [21, 22]. Because individual needs and enteral absorption are variable and preterm infants are at high risk for both, ID and iron toxicity, measuring iron status to individualize iron supplementation appears to be mandatory. Although many laboratory tests have been developed to assess iron status [reviewed in 23], there is consensus that no single blood test adequately reflects iron status in all circumstances. Beyond parameter-specific limitations, laboratory markers may be confounded by developmental changes occurring in utero. Consequently, this review aims to summarize published data on gestational age-specific cord blood concentrations of iron status parameters that might be suitable to guide iron supplementation in preterm infants.

\section{Materials and Methods}

We reviewed the literature searching PubMed for cord blood concentration of iron status parameters, and searched reference lists of retrieved publications for related publications. We attempted to contact the authors of all publications kindly requesting raw data to enable uniform presentation.

A Review of Cord Blood Concentrations of Iron Status Parameters
Extraction of data on mean, standard deviation (SD), or median and range for three gestational age groups: $23-29,30-36$, and 37-40 weeks was performed. If possible, data were transformed and shown as mean and reference range (defined as 2.5th and 97.5th percentiles $=$ mean $\pm 1.96 \times \mathrm{SD}$ ), and if normally distributed, a weighted mean was calculated. Not normally distributed data were not transformed and shown as extracted from the original publication. Raw data obtained from contacted authors were included in the tables and shown in a separate line below the original publication.

The majority of the reference ranges of adult iron status parameters were obtained from a standard textbook of clinical chemistry [24], reference ranges of females and males were transformed into a unisex mean.

\section{Results}

We identified 30 suitable publications regarding iron status parameters determined in cord blood. Sweet et al. $[25,26]$ as well as Ervasti et al. [27-29] used the same study population for more than one publication, and just one of each of these publications $[25,27]$ was listed in the tables. We contacted 22 of 30 corresponding authors of the original publications cited herein. The remaining 8 corresponding authors were not contacted because it was impossible to obtain a current valid email address. Of the 22 contacted corresponding authors, 5 answered without providing additional raw data, and 3 provided additional raw data, which we included in the tables in a separate line below the original publication.

In all publications providing details on cord clamping procedures, cord blood was obtained after immediate cord clamping [30-34].

\section{Hemoglobin}

Data on gestational age-specific cord blood concentrations of hemoglobin $(\mathrm{Hb})$ are displayed in table 1. There was a trend towards higher $\mathrm{Hb}$ levels with increasing gestational age. Adult reference ranges were lower than term, and higher than very preterm cord blood $\mathrm{Hb}$ levels.

\section{Mean Corpuscular Volume}

Gestational age-specific mean corpuscular volume $(\mathrm{MCV})$ values in cord blood are displayed in table $2 . \mathrm{MCV}$ in cord blood decreased with gestational age and was higher than adult MCV values.

\section{Ferritin}

Cord serum ferritin concentrations (table 3 ) increased with gestational age and were higher compared to adult levels. 
Table 1. Hb concentration $(\mathrm{g} / \mathrm{dl})$ in cord blood

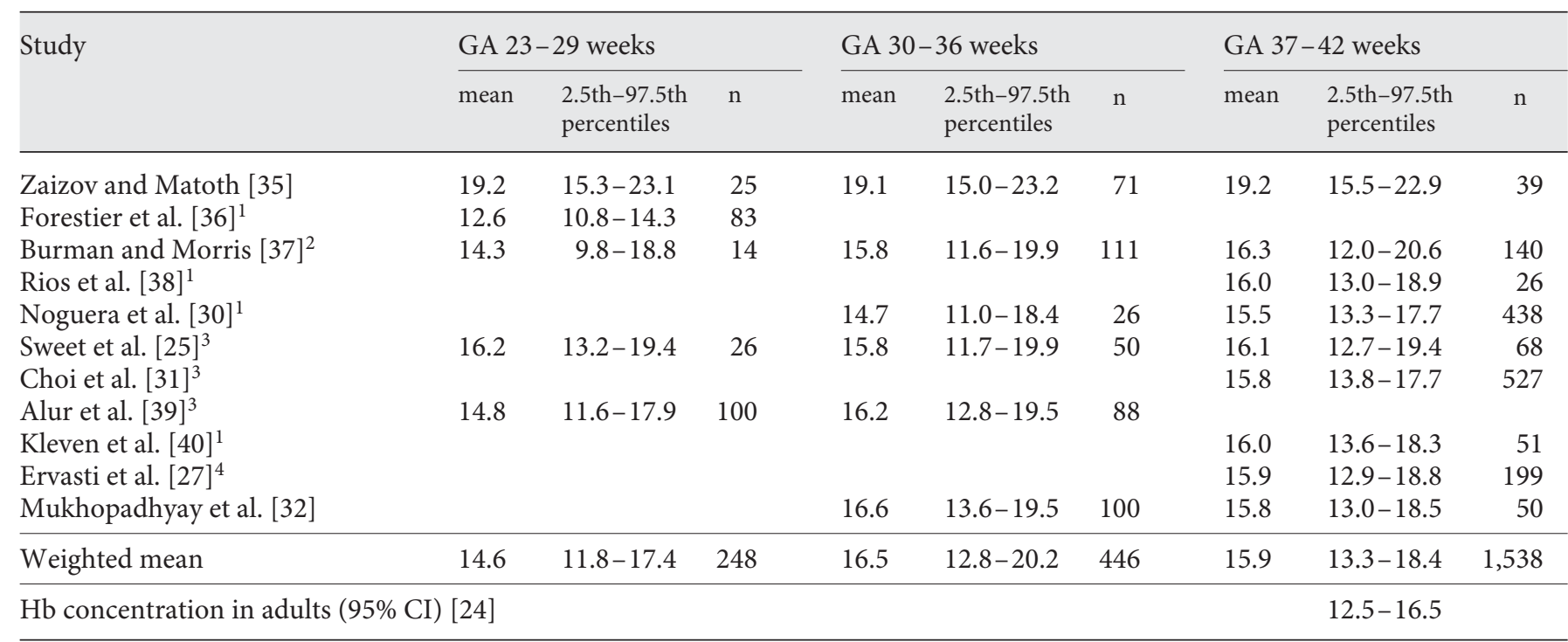

SI conversion factor: 0.6206 , SI unit: $\mathrm{mmol} / \mathrm{l}$.

${ }^{1}$ Coulter counter. ${ }^{2}$ Standard cyanomethemoglobin method. ${ }^{3}$ Sysmex. ${ }^{4}$ Advia.

Table 2. MCV (fl) in cord blood

\begin{tabular}{|c|c|c|c|c|c|c|c|c|c|}
\hline \multirow[t]{2}{*}{ Study } & \multicolumn{3}{|c|}{ GA $23-29$ weeks } & \multicolumn{3}{|c|}{ GA $30-36$ weeks } & \multicolumn{3}{|c|}{ GA 37-42 weeks } \\
\hline & mean & $\begin{array}{l}\text { 2.5th-97.5th } \\
\text { percentiles }\end{array}$ & $\mathrm{n}$ & mean & $\begin{array}{l}\text { 2.5th-97.5th } \\
\text { percentiles }\end{array}$ & $\mathrm{n}$ & mean & $\begin{array}{l}\text { 2.5th-97.5th } \\
\text { percentiles }\end{array}$ & $\mathrm{n}$ \\
\hline Zaizov and Matoth [35] & 132.5 & $112.5-152.5$ & 25 & 124.0 & $98.9-149.0$ & 71 & 120.0 & $98.4-141.5$ & 39 \\
\hline Forestier et al. $[36]^{1}$ & 124.2 & $112.2-135.9$ & 83 & & & & & & \\
\hline Noguera et al. $[30]^{1}$ & & & & 109.1 & $103.4-114.8$ & 26 & 105.1 & $94.7-115.5$ & 438 \\
\hline Ervasti et al. [27] ${ }^{3}$ & & & & & & & 109.0 & $101.1-116.8$ & 199 \\
\hline Weighted mean & 120.6 & $106.9-134.0$ & 208 & 115.4 & $98.8-131.9$ & 185 & 108.1 & $97.8-118.5$ & 1,203 \\
\hline MCV in adults (95\% CI) [24] & & & & & & & & $80-96$ & \\
\hline
\end{tabular}

Small for gestational age preterm infants had even lower cord serum ferritin levels (mean: $67 \mu \mathrm{g} / \mathrm{l}$ ) compared to appropriate for gestational age preterm infants (mean: $125 \mu \mathrm{g} / \mathrm{l})[2]$.

\section{Soluble Transferrin Receptor}

Data on gestational age-specific cord blood concentrations of sTfR are displayed in table 4 . Whereas KruiperKramer et al. [48] did not find an association between gestational age and sTfR concentrations according to a scatter plot, Sweet et al. [25] showed that increasing gestational age was associated with decreasing sTfR levels, and Hay et al. [43] demonstrated a positive correlation between sTfR and gestational age. In general, cord blood sTfR values tended to be higher than adult levels.

\section{Ferritin Index (sTfR/Ferritin)}

Ferritin index in cord blood decreased with gestational age [mean (reference range)]: gestational age at birth (GA) 23-29 weeks: 5.5 (3.3-8.6), n = 26; GA 30-36 weeks: 
Table 3. Ferritin concentration $(\mu \mathrm{g} / \mathrm{l})$ in cord blood

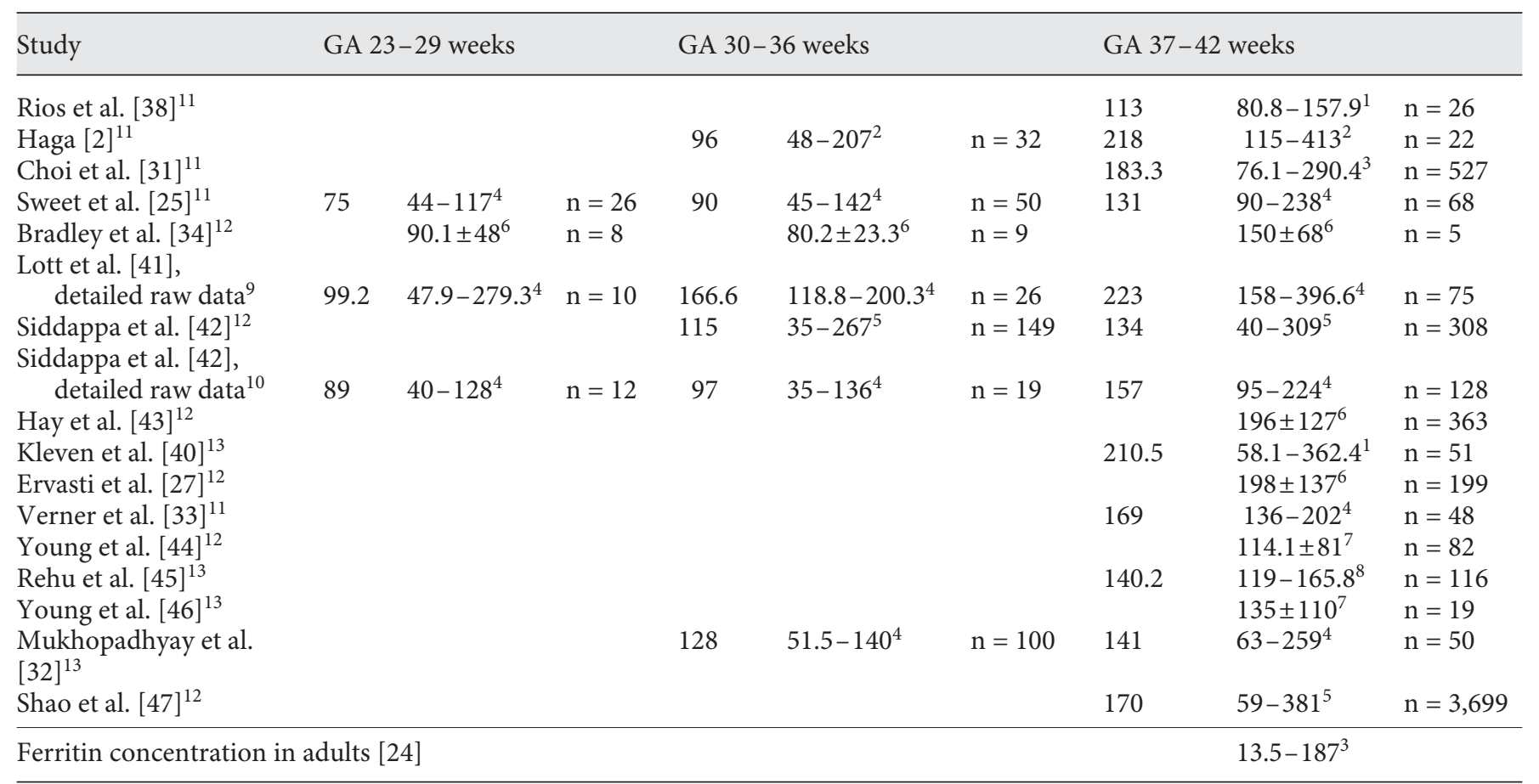

SI conversion factor: 2.247 , SI unit: pmol/l.

${ }^{1}$ Geometric mean, limits of 1 SD. ${ }^{2}$ Not mentioned. ${ }^{3}$ Mean and 2.5 th and 97.5 th percentiles $=1.96 \times$ SD. ${ }^{4}$ Median and interquartile range. ${ }^{5}$ 50th and 5 th and 95 th percentiles. ${ }^{6}$ Mean \pm SD. ${ }^{7}$ Median \pm SD. ${ }^{8}$ Geometric mean and $95 \%$ CI. ${ }^{9}$ Raw data obtained from Widness [pers. commun., 2013]. ${ }^{10}$ Raw data obtained from Siddappa [pers. commun., 2013]. ${ }^{11}$ Radioimmunoassay. ${ }^{12}$ Chemiluminescence immunoassay. ${ }^{13}$ Enzyme-linked immunosorbent assay.

$4.6(2.8-7.1), \mathrm{n}=50$; GA 37-42 weeks: 3.8 (3.0-3.2), $\mathrm{n}=$ 68 [25]. Ferritin index in cord blood was higher compared to adult levels (reference range: 0.6-1.8 [49]).

This difference cannot be explained by insufficient assay validation for sTfR, because the same immunoenzymometric assay has been used for both, cord blood and adult values. Cord blood values for ferritin index obtained with an automated immunoturbidometric IdeA TfR-IT assay were lower [GA 37-42 weeks: $0.9(0.1-1.8), \mathrm{n}=199$ [27]].

\section{Transferrin Saturation}

Data on gestational age-specific cord blood values of transferrin saturation (TS) are displayed in table 5. TS values increased with gestational age and were higher compared to adult levels.

\section{Reticulocyte Hb Content}

Reticulocyte hemoglobin content $(\mathrm{CHr})$ values in cord blood of preterm infants have not yet been reported. $\mathrm{CHr}$ values of term infants [mean (referene range): $35.6 \mathrm{pg}$
(33.0-38.1), $\mathrm{n}=199$ [27], and geometric mean (95\% confidence interval (CI)): $35.6 \mathrm{pg}(35.3-36.0), \mathrm{n}=116$ [45]] were both higher compared to adult values (reference range: $28-35 \mathrm{pg}$ [24]).

\section{Zinc Protoporphyrin/Heme Ratio}

Data on gestational age specific cord blood values of $\mathrm{ZnPP} / \mathrm{H}$ are displayed in table 6 . There is a negative correlation of $\mathrm{ZnPP} / \mathrm{H}$ with gestational age and adult reference ranges seem to be lower.

\section{Hepcidin}

Hepcidin concentrations in cord blood of preterm infants have not been reported, but in term infants [geometric mean (95\% CI): $72.3 \mathrm{ng} / \mathrm{ml}(20.5-231.9), \mathrm{n}=137$ [45], and median (SD): $61.7 \mathrm{ng} / \mathrm{ml}$ (77.0), $\mathrm{n}=19$ [46]], values are similar to those in adults [mean (95\% CI): 90.7 $\mathrm{ng} / \mathrm{ml}$ (23.8-267.7) [56]]. All hepcidin concentrations were measured with a competitive enzyme-linked immunosorbent assay. 
Table 4. sTfR concentration (mg/l) in cord blood

\begin{tabular}{|c|c|c|c|c|c|c|c|}
\hline \multirow{2}{*}{$\begin{array}{l}\text { Study } \\
\text { Choi et al. }[31]^{5}\end{array}$} & \multicolumn{2}{|l|}{ GA $23-29$ weeks } & \multicolumn{2}{|l|}{ GA $30-36$ weeks } & \multicolumn{3}{|c|}{ GA $37-42$ weeks } \\
\hline & & & & & 5.7 & $4.4-6.9^{1}$ & $\mathrm{n}=527$ \\
\hline Sweet et al. $[25]^{5}$ & $10.37 .5-16.5^{2}$ & $\mathrm{n}=26$ & $8.25 .4-12.3^{2}$ & $\mathrm{n}=50$ & 8.4 & $6.4-10.6^{2}$ & $\mathrm{n}=68$ \\
\hline Hay et al. $[43]^{5}$ & & & & & 7.1 & $5.5-9.6^{2}$ & $\mathrm{n}=350$ \\
\hline Young et al. $[44]^{5}$ & & & & & & $8.0 \pm 2.4^{3}$ & $\mathrm{n}=83$ \\
\hline Young et al. $[46]^{5}$ & & & & & 8.4 & $3.1-13.7^{1}$ & $\mathrm{n}=19$ \\
\hline Verner et al. $[33]^{5}$ & & & & & 12.9 & $8.3-18.7^{2}$ & $\mathrm{n}=48$ \\
\hline Ervasti et al. $[27]^{6}$ & & & & & 2.0 & $0.6-3.3^{1}$ & $\mathrm{n}=199$ \\
\hline Rehu $[45]^{6}$ & & & & & 1.9 & $1.8-2.1^{4}$ & $\mathrm{n}=116$ \\
\hline sTfR concentration in adults $[49]^{5}$ & & & & & & $1.1-2.7^{1}$ & \\
\hline
\end{tabular}

${ }^{1}$ Mean and 2.5th and 97.5th percentiles $=1.96 \times$ SD. ${ }^{2}$ Median and interquartile range. ${ }^{3}$ Median and SD. ${ }^{4}$ Geometric mean and $95 \%$ CI. ${ }^{5}$ Immunoenzymometric assay. ${ }^{6}$ Automated immunoturbidometric IdeA TfR-IT assay.

Table 5. TS (\%) in cord blood

\begin{tabular}{|c|c|c|c|c|c|c|c|c|c|}
\hline Study & \multicolumn{3}{|c|}{ GA 23-29 weeks } & \multicolumn{3}{|c|}{ GA $30-36$ weeks } & \multicolumn{3}{|c|}{ GA $37-42$ weeks } \\
\hline Rios et al. [38] & & & & & & & 59.5 & $33.0-84.9$ & 26 \\
\hline Haga [2] & & & & 46.5 & $6.5-86.5$ & 29 & 55 & $27.6-82.4$ & 21 \\
\hline Choi et al. [31] ${ }^{1}$ & & & & & & & 63.9 & $36.8-91.0$ & 527 \\
\hline
\end{tabular}

${ }^{1}$ Iron + total iron binding capacity: automatic chemical analyzer. ${ }^{2}$ Iron + transferrin: image analyzer.

Table 6. $\mathrm{ZnPP} / \mathrm{H}$ ratio $(\mu \mathrm{mol} / \mathrm{mol})$ in cord blood

\begin{tabular}{|c|c|c|c|c|c|c|c|c|c|}
\hline $\begin{array}{l}\text { Study } \\
\text { Juul et al. }[50]^{7}\end{array}$ & 111.7 & $60.7-162.6^{1}$ & $\mathrm{n}=26$ & 79.0 & $49.6-108.4^{1}$ & $\mathrm{n}=26$ & 79.0 & $49.6-108.4^{1}$ & $\mathrm{n}=26$ \\
\hline Lott et al. $[41]^{7}$ & 108.0 & $96.0-120.0^{2}$ & $\mathrm{n}=7$ & 84.0 & $78.0-90.0^{2}$ & $\mathrm{n}=12$ & 73.0 & $66.0-80.0^{2}$ & $\mathrm{n}=81$ \\
\hline Lott et al. [41], detailed raw data ${ }^{5}$ & 96.8 & $83.4-137.2^{3}$ & $\mathrm{n}=10$ & 78.3 & $57.4-98.5^{3}$ & $\mathrm{n}=26$ & 63.5 & $51.5-76^{3}$ & $\mathrm{n}=75$ \\
\hline Kling $[51]^{7}$ & 125.0 & $78.0-180.0^{2}$ & $\mathrm{n}=12$ & 90.0 & $42.0-162.0^{2}$ & $\mathrm{n}=84$ & 70.0 & $32.0-180.0^{2}$ & $\mathrm{n}=293$ \\
\hline Lesser et al. $[52]^{7}$ & & & & & & & 66.4 & $9.6-123.2^{1}$ & $\mathrm{n}=31$ \\
\hline \multirow{4}{*}{$\begin{array}{l}\text { Kleven et al. [40], Kling [51], } \\
\text { Lesser et al. [52], } \\
\text { Baumann-Blackmore et al. [54], } \\
\text { detailed raw data }^{6}\end{array}$} & & & & & & & & & \\
\hline & & & & & & & & & \\
\hline & & & & & & & 830 & 71 & \\
\hline & & & & & & & 05.9 & $15.1-152.1$ & $11=200$ \\
\hline $\mathrm{ZnPP} / \mathrm{H}$ ratio in adults [55] & & & & & & & & $30-80^{4}$ & \\
\hline
\end{tabular}

\footnotetext{
${ }^{1}$ Mean and 2.5th and 97.5th percentiles $=1.96 \times$ SD. ${ }^{2}$ According to the figure. ${ }^{3}$ Median and interquartile range. ${ }^{4}$ Reference range.

${ }^{5}$ Raw data obtained from Widness [pers. commun., 2013]. ${ }^{6}$ Raw data obtained from Kling [pers. commun., 2012]. ${ }^{7}$ Hematofluorometer.
} 


\section{Discussion}

This review summarizes gestational age-specific cord blood values of iron status parameters as surrogate reference ranges for preterm infants. It is important to realize that cord blood concentrations of these parameters are markedly different from reference ranges established for adults, and thus cutoff values to define the need for iron supplementation derived from adults or older children may not be appropriate for preterm infants.

Furthermore, all iron status parameters have specific limitations, which may be of particular importance in the preterm population.

$\mathrm{Hb}$, derived from the entire population of RBCs with a mean life span of 60 days in neonates [57] provides a very delayed response to developing ID. Moreover, $\mathrm{Hb}$ concentration depends on the blood sampling technique: it may be up to $15 \%$ higher when obtained from capillary compared to venous samples [58].

$\mathrm{MCV}$ is also a poor indicator of iron status in preterm infants, because of the physiological transition from fetal erythrocytes characterized by high MCV and predominantly containing fetal $\mathrm{Hb}$ to adult erythrocytes characterized by lower MCV and predominantly containing adult $\mathrm{Hb}[35,39,59]$.

High or increased ferritin levels may not only indicate filled iron stores (e.g. following multiple RBC transfusions) or even iron overload conditions (i.e. in neonatal hemochromatosis), but also liver cell injury, or systemic inflammatory response [reviewed in 60], the latter being particularly common in preterm infants.

Increased sTfR concentrations are not specific for iron-deficient anemia but can also be observed in hyperproliferative erythropoiesis, e.g. due to hemolysis or ineffective erythropoiesis [61], and potentially also during erythropoietin administration for prevention and treatment of anemia of prematurity [62]. Furthermore, there are sex-specific differences with higher concentration of sTfR in male compared to female term infants [31, 43]. However the major limitation of sTfR is the lack of assay standardization with a high discrepancy between results from different commercially available tests [63].

TS is a late parameter for diagnosing ID, and it is low only when the iron stores are already exhausted [reviewed in 64].

In contrast, $\mathrm{CHr}$ is an early marker of functional ID because of the short lifespan of reticulocytes of just about $24 \mathrm{~h}$. The $\mathrm{ZnPP} / \mathrm{H}$ fluorometric determination can be influenced by plasma bilirubin, which needs to be washed out before analysis [65]. $\mathrm{ZnPP} / \mathrm{H}$ and $\mathrm{CHr}$ have the ad- vantage that they do not seem to be affected by chronic inflammatory disease or acute infection $[66,67]$, whereas hepcidin expression is also upregulated by inflammatory cytokines [68] and systemic inflammation [69] just like ferritin. On the other hand, hepcidin is also downregulated by hypoxia [70]. One of the biggest problems concerning hepcidin measurements both with immunochemical- and mass spectrometric assays is the lack of assay standardization and the availability of routine testing [71].

The more recent parameters to assess iron status like hepcidin and $\mathrm{ZnPP} / \mathrm{H}$ lack inter-assay standardization, which limits the validity of a reference range based on data obtained with different assays. The more established parameters like ferritin and $\mathrm{Hb}$ have been progressively developed over the last decades, potentially limiting the validity of a summary of older and more recent data. It is important to have this limitation in mind when using the reference ranges reported here in clinical practice.

The increase in ferritin, TS (and $\mathrm{Hb}$ ) and the decrease in ferritin index and $\mathrm{ZnPP} / \mathrm{H}$ with increasing gestational age may well reflect improved iron availability and growing iron stores during late gestation. In contrast, the observed decrease in MCV values can potentially be explained by the above-mentioned transition from fetal to adult erythrocytes. Controversial data were found for the association of sTfR with gestational age, probably because of a lack of assay standardization. No data have yet been published on the association between both $\mathrm{CHr}$ and hepcidin, and gestational age.

For all iron status parameters, higher values were observed in cord blood compared to adult blood. This may be due to high iron transfer from mother to fetus (explaining higher cord blood values for ferritin, $\mathrm{Hb}, \mathrm{TS}$ ) and maximally stimulated erythropoiesis (explaining higher values for STfR and ferritin index) at the end of gestation.

Moreover, lower ferritin levels indicating lower iron stores were observed not only in preterm infants [26] but also in infants with placental insufficiency [2] or maternal gestational diabetes mellitus [33] leading to a higher vulnerability to ID. In preterm infants, high postnatal growth velocity [4] and uncompensated iatrogenic blood loss [5] further contribute to an even earlier depletion of iron stores.

Iron stores acquired in utero are adequate until approximately the time that birthweight is doubled [72], and this occurs much earlier in premature infant compared to term infants - at least under the rather rare condition that iron losses from phlebotomy are matched by 
iron acquired by enteral iron absorption and blood transfusions. Consequently, to prevent anemia of prematurity, preterm infants should receive iron supplementation [21, 22 ], which can be standardized (i.e. every infant is given a standard dose of $2-4 \mathrm{mg} / \mathrm{kg}$ ) or individualized (i.e. based on the current iron needs of a given infant). Because iron stores cannot be assessed directly, the individual infant's actual iron status parameter concentrations have to be compared with reference ranges to assess the infant's individual iron need. The latter approach can take into account changes in iron needs based on blood transfusions (taking into account that every milliliter of blood transfused equals a parenteral administration of iron [73]), ongoing enteral iron supplementation, and phlebotomy losses. Because reference ranges derived from postnatal blood samples in preterm infants likely reflect iron supplementation, blood transfusion and phlebotomy practice of the individual unit rather than the physiological range of iron status at this developmental stage, we hypothesize that cord blood reference ranges may better guide individualized supplementation. Similarly, we hypothesize that cord blood reference ranges are more appropriate than the frequently used adult reference ranges [e.g. 74].

Whatever laboratory parameter is currently used to assess iron status, its determination adds to iatrogenic blood and, hence, iron loss and consequently further predisposes the preterm infant to ID. Every milliliter of blood loss represents a loss of 0.35-0.5 mg iron (assuming an $\mathrm{Hb}$ concentration of $10-15 \mathrm{~g} / \mathrm{dl}$ ). In very low-birthweight infants, iron losses due to phlebotomy can amount up to $6 \mathrm{mg} / \mathrm{kg} /$ week [75]. Therefore, it is desirable to search for a method to measure iron status without causing additional blood loss. Hepcidin, which to date is the only parameter that can also be measured in urine $[56,69]$, could serve with some limitations as a parameter to monitor iron status in preterm and term infants without contributing to further blood loss, at least in the absence of systemic inflammation.

Because of the high number of confounding intrauterine as well as postnatal variables that may influence iron status parameters and the fact that measuring iron status parameters leads to further blood loss, standardized iron supplementation is probably still appropriate in preterm infants. However, infants with ID have been described despite standardized iron supplementation, which may not meet the needs of all infants [10].

\section{Conclusion}

Reference ranges of iron status parameters established for adults are remarkably different from cord blood values and consequently may not be suitable to guide iron supplementation in preterm infants. Because of inherent limitations of iron status parameters, a standardized iron supplementation to prevent anemia of prematurity still seems to be justified as long as an individualized supplementation, e.g. on the basis of gestational age-specific reference ranges, has not been proven superior.

\section{Acknowledgement}

The study was supported by AKF grant No. 283-0-0 from the Faculty of Medicine, University of Tübingen (L.L.).

The authors thank Pamela J. Kling, Ashajyothi M. Siddappa, and John Widness (supported by NIH HD 29421), for sending helpful raw data on $\mathrm{CHr}$, ferritin and $\mathrm{ZnPP} / \mathrm{H}$ in cord blood, and Kanya Mukhopadhyay, Raghavendra Rao, Michael K. Georgieff, and David Sweet, for providing additional information.

\section{References}

1 Rao R, Georgieff MK: Iron in fetal and neonatal nutrition. Semin Fetal Neonatal Med 2007; 12:54-63.

$>2$ Haga P: Plasma ferritin concentrations in preterm infants in cord blood and during the early anaemia of prematurity. Acta Paediatr Scand 1980;69:637-641.

3 Widdowson EM, Spray CM: Chemical development in utero. Arch Dis Child 1951;26: 205-214.

$>4$ Niklasson A, Engstrom E, Hard AL, Wikland KA, Hellstrom A: Growth in very preterm children: a longitudinal study. Pediatr Res 2003;54:899-905.
5 Widness JA, Madan A, Grindeanu LA, Zimmerman MB, Wong DK, Stevenson DK: Reduction in red blood cell transfusions among preterm infants: results of a randomized trial with an in-line blood gas and chemistry monitor. Pediatrics 2005;115: 1299-1306.

6 Grantham-McGregor S, Ani C: A review of studies on the effect of iron deficiency on cognitive development in children. J Nutr 2001; 131:649S-666S, discussion 666S-668S.

$>7$ Lozoff B, Georgieff MK: Iron deficiency and brain development. Semin Pediatr Neurol 2006;13:158-165.
8 Armony-Sivan R, Eidelman AI, Lanir A, Sredni D, Yehuda S: Iron status and neurobehavioral development of premature infants. J Perinatol 2004;24:757-762.

$\checkmark 9$ Siimes MA, Addiego JE Jr, Dallman PR: Ferritin in serum: diagnosis of iron deficiency and iron overload in infants and children. Blood 1974;43:581-590.

10 Franz AR, Mihatsch WA, Sander S, Kron M, Pohlandt F: Prospective randomized trial of early versus late enteral iron supplementation in infants with a birth weight of less than 1301 grams. Pediatrics 2000;106:700-706. 
-11 Steinmacher J, Pohlandt F, Bode H, Sander S, Kron M, Franz AR: Randomized trial of early versus late enteral iron supplementation in infants with a birth weight of less than $1,301 \mathrm{~g}$ : neurocognitive development at 5.3 years' corrected age. Pediatrics 2007;120:538-546.

- 12 McDonald MC, Abrams SA, Schanler RJ: Iron absorption and red blood cell incorporation in premature infants fed an iron-fortified infant formula. Pediatr Res 1998;44:507511.

-13 Widness JA, Serfass RE, Haiden N, Nelson SE, Lombard KA, Pollak A: Erythrocyte iron incorporation but not absorption is increased by intravenous iron administration in erythropoietin-treated premature infants. J Nutr 2006;136:1868-1873.

14 Sullivan JL: Iron, plasma antioxidants, and the 'oxygen radical disease of prematurity'. Am J Dis Child 1988;142:1341-1344.

15 Friel JK, Aziz K, Andrews WL, Serfass RE: Iron absorption and oxidant stress during erythropoietin therapy in very low birth weight premature infants: a cohort study. BMC Pediatr 2005;5:29.

16 Miller SM, McPherson RJ, Juul SE: Iron sulfate supplementation decreases zinc protoporphyrin to heme ratio in premature infants. J Pediatr 2006;148:44-48.

17 Braekke K, Bechensteen AG, Halvorsen BL, Blomhoff R, Haaland K, Staff AC: Oxidative stress markers and antioxidant status after oral iron supplementation to very low birth weight infants. J Pediatr 2007;151:23-28.

18 Idjradinata P, Watkins WE, Pollitt E: Adverse effect of iron supplementation on weight gain of iron-replete young children. Lancet 1994; 343:1252-1254.

-19 Dewey KG, Domellof M, Cohen RJ, Landa Rivera $\mathrm{L}$, Hernell $\mathrm{O}$, Lonnerdal B: Iron supplementation affects growth and morbidity of breast-fed infants: results of a randomized trial in Sweden and Honduras. J Nutr 2002; 132:3249-3255

20 Berglund S, Westrup B, Domellof M: Iron supplements reduce the risk of iron deficiency anemia in marginally low birth weight infants. Pediatrics 2010;126:e874-e883.

21 Baker RD, Greer FR: Diagnosis and prevention of iron deficiency and iron-deficiency anemia in infants and young children (0-3 years of age). Pediatrics 2010;126:1040-1050.

-22 Agostoni C, Buonocore G, Carnielli VP, De Curtis M, Darmaun D, Decsi T, Domellof M, Embleton ND, Fusch C, Genzel-Boroviczeny O, Goulet O, Kalhan SC, Kolacek S, Koletzko B, Lapillonne A, Mihatsch W, Moreno L, Neu J, Poindexter B, Puntis J, Putet G, Rigo J, Riskin A, Salle B, Sauer P, Shamir R, Szajewska $H$, Thureen $P$, Turck D, van Goudoever JB, Ziegler EE: Enteral nutrient supply for preterm infants: commentary from the European Society of Paediatric Gastroenterology, Hepatology and Nutrition Committee on $\mathrm{Nu}$ trition. J Pediatr Gastroenterol Nutr 2010;50: 85-91.
23 Mei Z, Cogswell ME, Parvanta I, Lynch S, Beard JL, Stoltzfus RJ, Grummer-Strawn LM: Hemoglobin and ferritin are currently the most efficient indicators of population response to iron interventions: an analysis of nine randomized controlled trials. J Nutr 2005; 135:1974-1980.

24 Thomas L: Labor und Diagnose: Indikation und Bewertung von Laborbefunden für die medizinische Diagnostik, ed 7. Frankfurt/ Main, TH-Books, 2008.

25 Sweet DG, Savage GA, Tubman R, Lappin TR, Halliday HL: Cord blood transferrin receptors to assess fetal iron status. Arch Dis Child Fetal Neonatal Ed 2001;85:F46-F48.

26 Sweet DG, Savage G, Tubman TR, Lappin TR, Halliday HL: Study of maternal influences on fetal iron status at term using cord blood transferrin receptors. Arch Dis Child Fetal Neonatal Ed 2001;84:F40-F43.

27 Ervasti M, Kotisaari S, Sankilampi U, Heinonen S, Punnonen K: The relationship between red blood cell and reticulocyte indices and serum markers of iron status in the cord blood of newborns. Clin Chem Lab Med 2007; 45:1000-1003.

28 Ervasti M, Sankilampi U, Heinonen S, Punnonen K: Novel red cell indices indicating reduced availability of iron are associated with high erythropoietin concentration and low $\mathrm{ph}$ level in the venous cord blood of newborns. Pediatr Res 2008;64:135-140.

29 Ervasti M, Sankilampi U, Heinonen S, Punnonen K: Early signs of maternal iron deficiency do not influence the iron status of the newborn, but are associated with higher infant birthweight. Acta Obstet Gynecol Scand 2009;88:83-90.

30 Noguera NI, Detarsio G, Perez SM, Bragos IM, Lanza O, Rodriguez JH, Acosta I, Davoli R, Milani AC: Hematologic study of newborn umbilical cord blood. Medicina (B Aires) 1999;59:446-448.

- 31 Choi JW, Kim CS, Pai SH: Erythropoietic activity and soluble transferrin receptor level in neonates and maternal blood. Acta Paediatr 2000;89:675-679.

-32 Mukhopadhyay K, Yadav RK, Kishore SS, Garewal G, Jain V, Narang A: Iron status at birth and at 4 weeks in preterm-SGA infants in comparison with preterm and term-AGA infants. J Matern Fetal Neonatal Med 2012;25: 1474-1478.

33 Verner AM, Manderson J, Lappin TR, McCance DR, Halliday HL, Sweet DG: Influence of maternal diabetes mellitus on fetal iron status. Arch Dis Child Fetal Neonatal Ed 2007; 92:F399-F401.

34 Bradley J, Leibold EA, Harris ZL, Wobken JD, Clarke S, Zumbrennen KB, Eisenstein RS, Georgieff MK: Influence of gestational age and fetal iron status on IRP activity and iron transporter protein expression in third-trimester human placenta. Am J Physiol Regul Integr Comp Physiol 2004;287:R894-R901.
5 Zaizov R, Matoth Y: Red cell values on the first postnatal day during the last 16 weeks of gestation. Am J Hematol 1976;1:275-278.

- 36 Forestier F, Daffos F, Galacteros F, Bardakjian J, Rainaut M, Beuzard Y: Hematological values of 163 normal fetuses between 18 and 30 weeks of gestation. Pediatr Res 1986;20:342346.

37 Burman D, Morris AF: Cord haemoglobin in low birthweight infants. Arch Dis Child 1974; 49:382-385.

38 Rios E, Lipschitz DA, Cook JD, Smith NJ: Relationship of maternal and infant iron stores as assessed by determination of plasma ferritin. Pediatrics 1975;55:694-699.

39 Alur P, Devapatla SS, Super DM, Danish E, Stern T, Inagandla R, Moore JJ: Impact of race and gestational age on red blood cell indices in very low birth weight infants. Pediatrics 2000;106:306-310.

40 Kleven KJ, Blohowiak SE, Kling PJ: Zinc protoporphyrin/heme in large-for-gestation newborns. Neonatology 2007;92:91-95.

41 Lott DG, Zimmerman MB, Labbe RF, Kling PJ, Widness JA: Erythrocyte zinc protoporphyrin is elevated with prematurity and fetal hypoxemia. Pediatrics 2005;116:414-422.

42 Siddappa AM, Rao R, Long JD, Widness JA, Georgieff MK: The assessment of newborn iron stores at birth: a review of the literature and standards for ferritin concentrations. Neonatology 2007;92:73-82.

43 Hay G, Refsum H, Whitelaw A, Melbye EL, Haug E, Borch-Iohnsen B: Predictors of serum ferritin and serum soluble transferrin receptor in newborns and their associations with iron status during the first 2 years of life. Am J Clin Nutr 2007;86:64-73.

44 Young MF, Pressman E, Foehr ML, McNanley T, Cooper E, Guillet R, Orlando M, McIntyre AW, Lafond J, O’Brien KO: Impact of maternal and neonatal iron status on placental transferrin receptor expression in pregnant adolescents. Placenta 2010;31:1010-1014.

45 Rehu M, Punnonen K, Ostland V, Heinonen S, Westerman M, Pulkki K, Sankilampi U: Maternal serum hepcidin is low at term and independent of cord blood iron status. Eur J Haematol 2010;85:345-352.

46 Young MF, Griffin I, Pressman E, McIntyre AW, Cooper E, McNanley T, Harris ZL, Westerman M, O'Brien KO: Maternal hepcidin is associated with placental transfer of iron derived from dietary heme and nonheme sources. J Nutr 2012;142:33-39.

47 Shao J, Lou J, Rao R, Georgieff MK, Kaciroti N, Felt BT, Zhao ZY, Lozoff B: Maternal serum ferritin concentration is positively associated with newborn iron stores in women with low ferritin status in late pregnancy. J Nutr 2012;142:2004-2009.

48 Kuiper-Kramer EP, Baerts W, Bakker R, van Eyck J, van Raan J, van Eijk HG: Evaluation of the iron status of the newborn by soluble transferrin receptors in serum. Clin Chem Lab Med 1998;36:17-21. 
49 Suominen P, Punnonen K, Rajamaki A, Irjala $\mathrm{K}$ : Serum transferrin receptor and transferrin receptor-ferritin index identify healthy subjects with subclinical iron deficits. Blood 1998;92:2934-2939.

-50 Juul SE, Zerzan JC, Strandjord TP, Woodrum DE: Zinc protoporphyrin/heme as an indicator of iron status in NICU patients. J Pediatr 2003; 142:273-278.

51 Kling PJ: The zinc protoporphyrin/heme ratio in premature infants: has it found its place? J Pediatr 2006;148:8-10.

52 Lesser KB, Schoel SB, Kling PJ: Elevated zinc protoporphyrin/heme ratios in umbilical cord blood after diabetic pregnancy. J Perinatol 2006;26:671-676.

53 Cheng CF, Zerzan JC, Johnson DB, Juul SE: Zinc protoporphyrin-to-heme ratios in highrisk and preterm infants. J Pediatr 2012;161: 81-7.e1.

54 Baumann-Blackmore NL, Goetz E, Blohowiak SE, Zaka O, Kling PJ: Cord blood zinc protoporphyrin/heme ratio in minority neonates at risk for iron deficiency. J Pediatr 2008; 153 133-136.

55 Labbe RF: Zinc protoporphyrin/heme ratio as an indicator of marrow iron stores. Am J Clin Pathol 1991;95:758.

56 Ganz T, Olbina G, Girelli D, Nemeth E, Westerman M: Immunoassay for human serum hepcidin. Blood 2008;112:4292-4297.

-57 Bratteby LE, Garby L, Groth T, Schneider W, Wadman B: Studies on erythro-kinetics in infancy. 13. The mean life span and the life span frequency function of red blood cells formed during foetal life. Acta Paediatr Scand 1968; 57:311-320.

$58 \mathrm{Oh} \mathrm{W}$, Lind J: Venous and capillary hematocrit in newborn infants and placental transfusion. Acta Paediatr Scand 1966;55:38-48.
59 Olivieri NF: Fetal erythropoiesis and the diagnosis and treatment of hemoglobin disorders in the fetus and child. Semin Perinatol 1997; 21:63-69.

60 Jacobs A: Ferritin: an interim review. Curr Top Hematol 1985;5:25-62.

61 Kohgo Y, Niitsu Y, Kondo H, Kato J, Tsushima N, Sasaki K, Hirayama M, Numata T, Nishisato T, Urushizaki I: Serum transferrin receptor as a new index of erythropoiesis. Blood 1987;70:1955-1958.

62 Krallis N, Cholevas V, Mavridis A, Georgiou I, Bourantas K, Andronikou S: Effect of recombinant human erythropoietin in preterm infants. Eur J Haematol 1999;63:71-76.

63 Akesson A, Bjellerup P, Vahter M: Evaluation of kits for measurement of the soluble transferrin receptor. Scand J Clin Lab Invest 1999; 59:77-81.

64 Szoke D, Panteghini M: Diagnostic value of transferrin. Clin Chim Acta 2012;413:11841189.

65 Hastka J, Lasserre JJ, Schwarzbeck A, Strauch M, Hehlmann R: Washing erythrocytes to remove interferents in measurements of zinc protoporphyrin by front-face hematofluorometry. Clin Chem 1992;38:2184-2189.

66 Hastka J, Lasserre JJ, Schwarzbeck A, Strauch M, Hehlmann R: Zinc protoporphyrin in anemia of chronic disorders. Blood 1993;81: 1200-1204.

67 Brugnara C, Laufer MR, Friedman AJ, Bridges K, Platt O: Reticulocyte hemoglobin content $(\mathrm{CHr})$ : early indicator of iron deficiency and response to therapy. Blood 1994;83: 3100-3101.
68 Nemeth E, Rivera S, Gabayan V, Keller C, Taudorf S, Pedersen BK, Ganz T: IL-6 mediates hypoferremia of inflammation by inducing the synthesis of the iron regulatory hormone hepcidin. J Clin Invest 2004;113:1271-1276.

69 Muller KF, Lorenz L, Poets CF, Westerman M, Franz AR: Hepcidin concentrations in serum and urine correlate with iron homeostasis in preterm infants. J Pediatr 2012;160:949953.e2.

70 Nicolas G, Chauvet C, Viatte L, Danan JL, Bigard X, Devaux I, Beaumont C, Kahn A, Vaulont $\mathrm{S}$ : The gene encoding the iron regulatory peptide hepcidin is regulated by anemia, hypoxia, and inflammation. J Clin Invest 2002; 110:1037-1044.

71 Kroot JJ, Kemna EH, Bansal SS, Busbridge M, Campostrini N, Girelli D, Hider RC, Koliaraki V, Mamalaki A, Olbina G, Tomosugi N, Tselepis C, Ward DG, Ganz T, Hendriks JC, Swinkels DW: Results of the first international round robin for the quantification of urinary and plasma hepcidin assays: need for standardization. Haematologica 2009;94: 1748-1752.

72 Domellof M: Iron requirements in infancy. Ann Nutr Metab 2011;59:59-63.

73 Brown MS: Effect of transfusion and phlebotomy on serum ferritin levels in low birth weight infants. J Perinatol 1996;16:39-42.

-74 Kasper DC, Widness JA, Haiden N, Berger A, Hayde M, Pollak A, Herkner KR: Characterization and differentiation of iron status in anemic very low birth weight infants using a diagnostic nomogram. Neonatology 2009;95: 164-171.

-75 Obladen M, Sachsenweger M, Stahnke M: Blood sampling in very low birth weight infants receiving different levels of intensive care. Eur J Pediatr 1988;147:399-404. 